Uncle Tom on the Ballet Stage: Italy's Barbarous America, 1850-1900

Author(s): By Axel Körner

Reviewed work(s):

Source: The Journal of Modern History, Vol. 83, No. 4 (December 2011), pp. 721-752

Published by: The University of Chicago Press

Stable URL: http://www.jstor.org/stable/10.1086/662218

Accessed: 16/05/2012 04:33

Your use of the JSTOR archive indicates your acceptance of the Terms \& Conditions of Use, available at http://www.jstor.org/page/info/about/policies/terms.jsp

JSTOR is a not-for-profit service that helps scholars, researchers, and students discover, use, and build upon a wide range of content in a trusted digital archive. We use information technology and tools to increase productivity and facilitate new forms of scholarship. For more information about JSTOR, please contact support@jstor.org. 


\title{
Uncle Tom on the Ballet Stage: Italy's Barbarous America, 1850-1900*
}

\author{
Axel Körner \\ University College London
}

\section{UnCle Tom on Stage}

Giacomo Puccini's Fanciulla del West (1908), which featured the Californian gold fever of 1849, and Giuseppe Verdi's Un ballo in maschera (1859), set in seventeenth-century Boston, are today probably the most famous Italian representations of America on stage. Although very different in character, both operas present American life as a mixture of exoticism, vice, and violence, far from the idea of a society founded on the high principles of the European Enlightenment. ${ }^{1}$ But it is another stage work that arguably had a more lasting effect on how Italians discussed life in the United States. In 1853 Milan's Teatro alla Scala staged what was to become one of the greatest success stories in the history of Italian ballet: Bianchi e Neri, Giuseppe Rota's adaptation of Stowe's epochal novel of 1852, Uncle Tom's Cabin. ${ }^{2}$ Although

* This article is based on research for an Arts and Humanities Research Councilfunded project on "The American Way of Life: Images of the United States in Nineteenth-Century Europe and Latin-America" at University College London. Part of the research was completed while I was a member at the Institute for Advanced Study, Princeton, and I am grateful for its financial support and its help with the location of primary sources. I also would like to thank the Remarque Institute of New York University for supporting my work with a fellowship and the New York Public Library of the Arts at Lincoln Center for helping to locate primary sources. Katharina Rietzler and Federico Mazzini assisted with bibliographic research in London and at the Casa della Musica in Parma. Ivan Polancec polished my prose. This article owes a lot to comments and criticism I received from my colleagues on the AHRC project and those who attended the presentation of an earlier version of this article at the Institute of Historical Research in London, especially Maurizio Isabella, Nicola Miller, Roger Parker, Maike Thier, and Lucy Riall.

${ }^{1}$ Originally Verdi had intended to write an opera set in Sweden, based on the assassination of Gustaf III. The censors insisted on changes to the libretto and Verdi decided to move the plot across the Atlantic.

${ }^{2}$ Giuseppe Rota (music by Paolo Giorza), Bianchi e Neri (Milan, 1853), New York Public Library (NYPL), Walter Toscanini Collection (WTC), Libretti da Ballo (LdB), nos. 809 and 939. The ballet was also performed under the titles La Capanna di Tom (Bologna) or I Bianchi e I Negri (Turin). For a synopsis of the novel see Linda Williams, Playing the Race Card: Melodramas of Black and White from Uncle Tom to O. J. Simpson (Princeton, NJ, 2001), 47.

The Journal of Modern History 83 (December 2011): 721-752

(C) 2011 by The University of Chicago. 0022-2801/2011/8304-0001\$10.00

All rights reserved. 
rather a free adaptation of the novel in not more than six or seven scenes, the ballet presents the dehumanizing brutality of a slaveholding society with unfailing clarity.

This article argues that the performance of Bianchi e Neri in most major theaters of the Italian peninsula became the starting point for a critical assessment of life in the United States, in contrast to the many earlier representations of America as a land of liberty and opportunities. Bianchi e Neri transformed the ways in which Italians discussed and imagined life in the New World. Unlike the British and the French, who were fully aware of the extent of slavery in the New World and had participated in debates over abolition for several decades, Italians during the mid-nineteenth century had only limited experience of colonization, the slave trade, or the slave economy. In 1833, in an article on U.S. tariffs, Cattaneo had condemned the institution of slavery as an "offence against the laws of humanity," and in 1846 Mazzini wrote a poem expressing his hopes that the American Republic would put an end to this evil. ${ }^{3}$ However, for most Italians slavery was an issue either associated with ancient Rome or discussed in orientalizing images of nonEuropean societies, a discourse to which stage representations of slavery contributed during the nineteenth century. Slavery, for Italians, was a world very different from their own. As an early review of Rota's Bianchi e Neri argues, "slavery is a regrettable crime of remote countries, and has nothing to do with us, where before the law everybody is the same." In Italy's political and religious debates or in literary depictions of life in the New World, the problem had not received the same attention as it had in Britain, France, or Germany. In this respect Italy also differed from the experiences of Spain, Cuba, or Brazil, where throughout the nineteenth century abolition was at the center of political debates. However, during the years leading up to the American Civil War, Italian awareness of slavery changed dramatically, with striking effects on the ways in which Italians imagined America.

Bianchi e Neri prepared the ground for this change in perception and had a powerful effect on how Italians discussed political and social realities across the Atlantic, especially during and after the American Civil War. This article

${ }^{3}$ See Giuseppe Mazzini's poem "Prière a Dieu pour les planteurs par un exilé," quoted in Leopoldo Ramanzini, Una lettera di Garibaldi ad Abramo Lincoln (Vicenza, 1970), 10; Carlo Cattaneo, "Notizia sulla questione delle tariffe daziarie negli Stati Uniti d'America desunta da documenti officiali" (1833), in Cattaneo, Scritti economici, ed. Alberto Bertolino (Florence, 1956), 1:11-55, 30. The article was first published in the Milanese Annali Universali di Statistica. Another reflection on slavery is Cattaneo's passionate review of poems by Henry Wadsworth Longfellow (1807-82): Carlo Cattaneo, "Il poeta americano Longfellow," in his Scritti Letterari, ed. Piero Treves (Florence, 1981), 1:461-73, 462.

${ }^{4}$ La Fama del 1853: Rassegna di Scienze, Lettere, Arti, Industria e Teatri, November 14, 1853 . 
will first examine the history of Bianchi e Neri in connection with the Italian reception of Stowe's novel. Then the article will contextualize the ballet's role within wider Italian debates about life in the United States up to the turn of the century.

Along with established images of the United States as the epitome of a positively defined modernity, as a model republic, and as a land of opportunities, Italians also discussed America as a wild and barbarous country, as the negation of its own cultural values..$^{5}$ In this context barbarism can take the form of brutality associated with daily life in the United States, but it often also appears as the absence of civilization in a frontier society. Unlike modern stereotypes of anti-Americanism, perhaps this negative image of the United States was the product of a long and often painful process of learning and disillusionment. Originally positive images of the United States, still predominant during the earlier years of the Italian Risorgimento, were increasingly tainted by the idea that America's republican federalism did not necessarily work as a solution to Italy's own constitutional problems and that the United States had little in common with the ways in which a European Kulturnation defines itself. Confronted with these doubts about life in the New World, it is probably more than a coincidence that strong philosophical prejudice against America originated in Italy with the thought of the reactionary Savoyard Joseph de Maistre, although his attitude toward the United States was certainly not representative of North Italian intellectuals as a whole. ${ }^{6}$

Historiographical conceptions of the apparent appeal of the United States to Italians are often based on the historians' rather limited chronological scope of research. A vast literature on early Italian responses to the American War of Independence and the American Constitution during the first decades of the Risorgimento should not lead to the assumption that these ideas about the United States remained unchallenged throughout the Risorgimento and the decades after Unification. Likewise, fascination with the modernity of the American lifestyle only started toward the end of the nineteenth century, when larger numbers of Italians arrived in the United States not just as emigrants but also as travelers, with the specific aim of experiencing the modernity of the New World. Through travel writing and journalism, ideas about the United States' modernity then increasingly infiltrated Italy's cultural sphere during the late

${ }^{5}$ For the origins of this debate, see Philippe Roger, who demonstrates how certain philosophers considered the New World unfit for civilization due to its natural conditions: "Aufklärer gegen Amerika," in Amerika und Europa-Mars und Venus? Das Bild Amerikas in Europa, ed. Rudolf von Thadden and Alexandre Escudier (Göttingen, 2004), 16-34.

${ }^{6}$ Philippe Roger, The American Enemy: A Story of French Anti-Americanism (2002) (Chicago, 2005), 45. During the French Revolution Savoy was taken by France. De Maistre then worked in the service of the king of Sardinia. 
nineteenth century. However, in historiographical terms it is important also to analyze perceptions of America during the first years after Unification, coinciding with the traumatic events of the American Civil War and the period of Reconstruction. During this crucial period it was not only positive images, such as those of the American Constitution and the War of Independence, but also slavery, the Civil War, and later political corruption during the Reconstruction, that provoked debate over American affairs among Italians; ${ }^{7}$ and even during the later part of the nineteenth century, when illustrated magazines and the world fairs started to praise American consumer goods, Italy's intellectual embrace of German Idealism contrasted with the perceived materialism and positivism of the United States, and the supposed grossness and vulgarity of its citizens.

Rota's ballet, along with the translation of Stowe's novel, represented the starting point for a serious reexamination of what Italians thought they knew about the United States. While the Milanese literary review La Fama argued in 1853 that the ballet's painful representation of human barbarity made it almost impossible to enjoy the performance, ${ }^{8}$ its unparalleled success and the debates it generated pay tribute to the impact the ballet had on the ways Italians engaged with the subject of slavery in the United States. Almost a decade later, for the Gazzetta Musicale di Napoli Rota's work was still more than a ballet: "you could easily call it a drama without words." Commenting on the ballet's Neapolitan staging of December 1862, at the height of the American Civil War, one could hardly imagine a timelier program for a theater. ${ }^{9}$

Although initially it was not necessarily read in the same political or ideological terms we associate with Stowe's novel today, Bianchi e Neri was certainly more than just an entertaining dance show anticipating the twentiethcentury commercial musical. Regarding its specific theatrical genre, Bianchi $e$ Neri was what Italians referred to as ballo storico or eroico, usually performed at the leading theaters in conjunction with opera seria and financed through subscription by the theaters' box owners and by public subsidies. ${ }^{10}$

${ }^{7}$ Since 1864 the American War of Independence was part of the curriculum on which future Italian diplomats were examined: Monitore di Bologna, December 20, 1864.

${ }^{8}$ La Fama del 1853: Rassegna di Scienze, Lettere, Arti, Industria e Teatri, November 14, 1853. L'Italia Musicale speaks of "ferocious" scenes demonstrating the "degradation of human nature," "the more disgusting the closer they are to the truth" (November 12, 1853).

${ }^{9}$ Gazzetta Musicale di Napoli, December 7, 1862.

${ }^{10}$ On the role of ballet in Italian theaters, see Axel Körner, Politics of Culture in Liberal Italy: From Unification to Fascism (New York, 2009), chap. 2. Also José Sasportes, "La parola contro il corpo ovvero il melodramma nemico del ballo," La Danza Italiana 1 (Fall 1984): 21-42. 
Therefore it would be misleading to compare Bianchi e Neri with, for instance, the popular "Uncle Tom shows" staged all over Europe and America during the second half of the nineteenth century. For nineteenth-century Italian audiences, this particular genre of ballet was as important as opera itself, and the two genres, opera and ballet, often influenced one other. ${ }^{11}$ Early stagings of Bianchi e Neri at La Scala coincided with the premieres of some of the greatest works in the history of Italian opera, notably Verdi's trilogy, Rigoletto, Il Trovatore, and La Traviata. However, Bianchi e Neri was often more successful than the opera with which it was staged. In 1862 Naples scheduled Bianchi e Neri with Verdi's Un ballo in maschera. While the opera was a spectacular fiasco, the audience received Rota's ballet with great enthusiasm. ${ }^{12}$

Theater was at the center of municipal structures of sociability in Italy, and more than anywhere else in Europe, theater helped Italians to identify themselves as a Kulturnation. ${ }^{13}$ The repercussions of this art form reached well beyond the social elites who owned or rented the private boxes in the peninsula's most famous opera houses, the San Carlo in Naples, the Comunale in Bologna, or at La Scala in Milan. The loggione in the upper floors of these theaters were usually populated by an audience that was more mixed socially. Sheet music with piano or guitar arrangements of the current repertoire constituted an important aspect of the publishers' commercial strategy, while organ players and municipal bands carried the most important tunes of the current program into the piazza, appreciated by those sections of society who would not be able to afford to go to the theater. For many Italians these potpourris of popular tunes were the only music they ever heard performed.

Italian society in the nineteenth century was fractured not only along social divisions but also regionally. Inhabitants of the Papal States had little in common with people from Tuscany or Piedmont, and the majority of Sicilians or Calabresi knew little about people from Lombardy or the Veneto. Thanks

${ }^{11}$ For example, in 1838 the Teatro alla Scala had staged Antonio Cortesi's ballo storico, Nabuccodonosor, which became the model for Verdi's first great success, the opera Nabucco of 1842, NYPL, WTC, LdB, no. 432. There is a short reference to the ballo in Carlo Gatti, Il Teatro alla Scala nella storia e nell'arte (1778-1963) (Milan, 1964), 117. See also the introduction by Roger Parker in The Works of Giuseppe Verdi, ser. 1, operas, vol. 3 (Giuseppe Verdi, Nabucodonosor: Dramma lirico in four parts), ed. Roger Parker (Chicago and Milan, 1987), xi-xxvi.

${ }_{12}$ Gazzetta Musicale di Napoli, November 16 and 23, 1862; La Fama del 1862: Rassegna di Scienze, Lettere, Arti, Industria e Teatri, November 25, 1862. On negative responses to Verdi, see Axel Körner, "Music of the Future: Italian Theatres and the European Experience of Modernity between Unification and World War One," European History Quarterly 41, no. 2 (April 2011): 189-212.

${ }^{13}$ Carlotta Sorba, Teatri: L'Italia del Melodramma nell'età del Risorgimento (Bologna, 2001). 
to the activities of the impresari, opera and ballet were among the few cultural industries that toured the entire peninsula, spreading from some of the world's finest theaters in Milan, Venice, or Naples to countless municipal theaters in smaller cities and staging performances at markets and trade fairs. ${ }^{14} \mathrm{Re}-$ sponses may have differed regionally, but the same art was shared across the peninsula. Due to the limited availability of sources and the difficulties involved in interpreting these, writing the history of the reception of opera and ballet across different sections of Italian society constitutes a particular methodological challenge. ${ }^{15}$ Meanwhile, the fact that the same works were usually performed from north to south (often including the islands) makes theater a particularly interesting subject for research into nineteenth-century Italian culture. The musical press, with its network of correspondents all over the peninsula, contributed to spreading news about the current season of Italy's countless theaters, including - in the case of Rota's ballet—heated debates over slavery in the United States. ${ }^{16}$ This is the cultural and social context in which we have to imagine the performance of Bianchi e Neri: an event of Italian high culture, but one whose echoes reached well beyond the noble boxes of Italy's famous theaters, and one which certainly represents more than a curious episode in the history of Italian dance.

As early as 1854, just two years after the original publication of the novel, countless translations of Uncle Tom's Cabin existed, including translations into many "minor languages" such as Armenian, Slovenian, and Welsh. ${ }^{17}$ Soon stage adaptations started to appear. Although one needs to be careful in granting Stowe authorship of the numerous dramatizations of the novel, ${ }^{18}$ these adaptations are almost as old as the novel itself and represent a wellstudied aspect of the Stowe phenomenon. ${ }^{19}$ American newspapers referred to

${ }^{14}$ John Rosselli, The Opera Industry in Italy from Cimarosa to Verdi: The Role of the Impresario (Cambridge, 1987), and Rosselli, Music and Musicians in 19th Century Italy (London, 1991); Marcello De Angelis, Le carte dell'impresario: Melodrama e costume teatrale nell'ottocento (Florence, 1982); also Sorba, Teatri.

${ }^{15}$ On methodological issues, see Axel Körner, "The Risorgimento's Literary Canon and the Aesthetics of Reception: Some Methodological Considerations," Nations and Nationalism 15, no. 3 (July 2009): 410-18.

${ }^{16}$ Along with other sources and further periodicals, the main musical periodicals used for this article are L'Arpa (Bologna); La Fama: Rassegna di Scienze, Lettere, Arti, Industria e Teatri (Milan); Gazzetta Musicale di Milano (Milan); Gazzetta Musicale di Napoli (Naples); L'Italia Musicale (Milan); Il Trovatore. Giornale Letterario, Artistico, Teatrale con Illustrazioni (Turin).

${ }^{17}$ John MacKay, "The First Years of Uncle Tom's Cabin in Russia," in Transatlantic Stowe: Harriet Beecher Stowe and European Culture, ed. Denise Kohn, Sarah Meer, and Emily B. Todd (Iowa City, IA, 2006), 67-88, 69.

${ }_{18}$ Sarah Robbins, The Cambridge Introduction to Harriet Beecher Stowe (Cambridge, 2007), 76. An exception would be her Christian Slave play.

19 Stowe's other abolitionist and more radical novel, Dred, was also dramatized: 
the traveling shows economically as "U.T.C. companies" (Uncle Tom's Cabin companies). ${ }^{20}$ They were generally regarded as mediocre but often attracted even more spectators than the later Buffalo Bill shows. In Naples alone three theaters presented different stage adaptations of the novel in May 1853, including a version in local dialect. ${ }^{21}$ As Henry James noted, "the fate of Mrs. Stowe's picture was conclusive: it simply sat down wherever it lighted and made itself at home." 22

Often presenting white actors with black faces in a mix of comical and sentimental emotions, stage adaptations of Uncle Tom's Cabin can be read in many different ways, and not all of them were necessarily understood as abolitionist, with some of them even taking a proslavery position. ${ }^{23}$ However, Rota's Italian ballet represents more than just a casual attempt to make money from the success of a literary model. Within the genre of historical ballet, the choreographer was usually his own librettist. ${ }^{24}$ The Scala in Milan commissioned the work from one of the most celebrated stars of Italian ballet, the young dancer and choreographer Giuseppe Rota (b. Venice, 1823; d. Turin, 1865), described by the influential literary magazine Il Trovatore as " $i l$ Verdi della coreografia." 25 The music for the ballet was written by the successful theater composer Paolo Giorza. After its premiere in Milan, the ballet had thirty-five performances at Genoa's Carlo Felice in 1856, followed by another fifteen performances there in 1857 and a further twenty-two in 1861, becom-

Judie Newman, "Staging Black Insurrection: Dred on Stage," in The Cambridge Companion to Harriet Beecher Stowe, ed. Cindy Weinstein (Cambridge, 2004), 11330. It should be noted that most scholars have treated Uncle Tom as an American phenomenon, neglecting the novel's transatlantic dimension: Denise Kohn, Sarah Meer, and Emily B. Todd, "Reading Stowe as a Transatlantic Writer," in Transatlantic Stowe, xi-xxxi.

${ }^{20}$ Harry Birdoff, The World's Greatest Hit: Uncle Tom's Cabin (New York, 1947), 6.

${ }^{21}$ Joseph Rossi, “Uncle Tom's Cabin and Protestantism in Italy," American Quarterly 11, no. 3 (Autumn 1959): 416-24, 418.

22 Quoted in Williams, Playing the Race Card, 45.

${ }^{23}$ Birdoff, The World's Greatest Hit, 24-28; Robbins, The Cambridge Introduction to Harriet Beecher Stowe, 78-79. For an Italian equivalent of the Uncle Tom shows, see the periodical publication Il Teatro drammatico Napolitano di Luigi de Lise, which since 1855 issued every month a short piece of theater. In February 1856 appeared the fascicolo 13, La famiglia dello zio Tom.

${ }^{24}$ Selma Jeanne Cohen, "Feme di Gelosia! Italian Ballet Librettos, 1766-1865," Bulletin of the New York Public Library 67 (November 1963): 9, 555-64, 556. For the historian, ballet libretti constitute an interesting source because they offer a synopsis with commentary of all scenes, unlike opera libretti, which consist mainly of dialogues.

${ }^{25}$ Il Trovatore: Giornale Letterario, Artistico, Teatrale, January 6, 1858. 
ing one of Genoa's most successful ballets of the whole nineteenth century. ${ }^{26}$ An important center of the slave trade during the Middle Ages and the city of Christopher Columbus, Genoa was particularly interested in the ballet. In 1858 Bianchi e Neri was on schedule in Rome, Turin, and Bologna. Naples's San Carlo gave a total of thirty-seven performances in 1862/1863, before the ballet returned to Milan in 1863, and to Turin's Teatro Regio in 1873 and 1875, after the choreographer's death. ${ }^{27}$ Within a decade the ballet had appeared on the stages of all of Italy's major theaters.

In the history of Italian dance Giuseppe Rota is remembered for his own virtuosity as a ballerino, but also for having revived the Italian tradition of dramatic pantomime as a choreographer. ${ }^{28}$ The remarkable success of Bianchi e Neri was certainly based on the popularity of its literary source, ${ }^{29}$ but Rota also knew how to enliven the action through the skillful addition of ensemble scenes and brilliant pas de deux, starring Augusta Maywood, the first American dancer to win a place among the top-ranking ballerinas of Europe, a fact perceived as giving the plot additional authenticity. ${ }^{30}$ The reviews suggest that

${ }^{26}$ G. B. Valebona, Il Teatro Carlo Felice: Cronistoria di un secolo, 1828-1928 (Genoa, 1928), 348-57. The number of performances was usually not scheduled in advance, but depended on the work's success. For the continuing appreciation of the audience in Genoa, see Il Trovatore, May 21, 1856.

27 Carlo Gatti, Il Teatro alla Scala nella Storia e nell'arte: Cronologia (Milan, 1964), 195, 200; Carlo Marinelli Roscioni, ed., Il Teatro di San Carlo (Naples, 1988), $2: 361$. The fact that smaller theaters in medium-sized cities did not stage the piece had more to do with the fact that its cast of several hundred participants was too expensive for the smaller houses. Even at the San Carlo the role of ballet diminished during the second half of the century, and most productions were retakes from successful productions of La Scala. José Sasportes, "La Danza, 1737-1900," in Il Teatro di San Carlo, ed. Raffaele Ajello et al. (Naples, 1988), 1:365-96, 395.

${ }^{28}$ On the Italian mimo-drama (historical themes performed in several acts), see Edwin Binney, "Sixty Years of Italian Dance Prints," Dance Perspectives 53 (Spring 1973): 8-60, 17.

${ }^{29}$ The importance accorded to the literary source in this genre of ballet goes back to the eighteenth century and was not uncontroversial: Sasportes, "La parola contro il corpo," 22.

${ }^{30}$ Maywood (b. New York, 1825; d. Lemberg/Lvov, 1876) began her career as a child prodigy in the United States, the first American to become prima ballerina assoluta in Europe, spending many years in Italy, where she was the first ballerina to found her own touring company, complete with managers, soloists, corps de ballet, sets, and costumes. Susan Au, "Augusta Maywood," and Claudia Celi, "Giuseppe Rota," in International Encyclopedia of Dance (Oxford, 1998), 4:338-39 and 5:408-9; "Maywood, Augusta," in Mary Clarke and David Vaughan, eds., The Encyclopedia of Dance and Ballet (London, 1977), 231; Ivor Guest, "Balli presentati tra il 1845 e il 1854," La danza italiana, nos. 8-9 (Autumn 1990): 17-26, 23. For an 1851 picture of Maywood in dancing pose, see Binney, "Sixty Years of Italian Dance Prints," 22. Dancers crossed the Atlantic in both directions. During the 1860s Italian ballerinas also performed in American western and Buffalo Bill shows. See Concetta 
audiences not only responded well to the ballet's literary source, but that they were particularly appreciative of the optical effects and the way Rota choreographed his ballabiles. ${ }^{31}$ Turin used for its performance the same sets as for Meyerbeer's grand opera Le Prophète, giving us an idea of the splendor with which the ballet was staged. However, for the authorities as well as for some critics, the Turin staging appeared to have been rather too advanced in its natural exhibition of the female slaves, with the police suspending a number of ballerinas and causing the famous theater critic Francesco d'Arcais to complain that the production evoked the "whore of Babylon."32 Notwithstanding similar moments of crisis, the success of Bianchi e Neri lasted for several decades and established Rota as one of the leading choreographers of his time and an important innovator of the genre. His productions dominated Italian stages for more than a generation, and many of his original works were regularly restaged by other choreographers, even during the years when ballet became too expensive for many Italian theaters and developments within the operatic genre left little space for ballet productions. ${ }^{33}$

Considering the reputation of a choreographer like Rota, we should not attempt to explain the extraordinary success of Bianchi e Neri only with reference to concerns over the fate of American slaves. However, at the time Italian ballets often chose the victory of virtue and true love as their theme, and an emphasis on social justice was common in the genre. ${ }^{34}$ Hence Italians associated certain expectations with this genre, which the choreographer had to take into consideration when proposing a libro da ballo, the libretto with the synopsis of the work. Moreover, the reception of the work changed with the specific context of its performances. During the second round of performances in 1863, at the height of the American Civil War, the ballet made an important impact on Milanese audiences because it was read as a direct commentary on an issue of international politics that was closely covered in the newspapers - the first time that American politics played a major part in the Italian press. While Italy had just been unified, the American Union

Lo Iacono, "Manzotti \& Marenco: Il diritto di due autori," Nuova Rivista Musicale Italiana 3 (July-September 1987): 421-46, 443.

${ }^{31}$ La Fama del 1853: Rassegna di Scienze, Lettere, Arti, Industria e Teatri, November 14, 1853.

${ }^{32}$ Alberto Basso, Storia del Teatro Regio di Torino, vol. 2, Il teatro della città (Turin, 1976), 295; Mercedes Viale Ferrero, Storia del Teatro di Torino, vol. 3, La scenografia (Turin, 1980), 418.

${ }^{33}$ On the financial constraints, see Körner, Politics of Culture, chap. 2. Rota and Giorza continued their collaboration, including the ballets La Maschera o Le notti di Venezia and Cleopatra, both presented at La Scala in 1865, NYPL, WTC, LdB, nos. 849 and 850.

${ }^{34}$ Cohen, "Feme di Gelosia!" 555-64. 
seemed about to fall apart. The performance had also been a success ten years earlier, but then the piece was presented in rather a different context, that of the struggle for national independence, as a story about liberation: for the scene of the slave rebellion Rota had asked the composer to introduce four bars of the Marseillaise into the score. When the Milanese audience exploded into applause during this scene, the Austrian police suspended the performance ${ }^{35}$ Hence even if the work's reception changed with the context of its performance history, its success was more than just the consequence of the choreographer's own popularity or of his tear-jerking subject. From the very beginning Bianchi e Neri was read politically. In the context of the ballet's performance, America was compared to and put on equal terms with the despotism of the ancien régime, very much in contrast to the idea of a country based on Enlightenment ideals.

\section{IMAGINING SLAVERY}

The success of Uncle Tom made Stowe "the most internationally visible American writer of her time," ${ }^{36}$ and arguably her novel had a more important impact on images of the United States than De Tocqueville's writings, for instance, or even those of Cooper. The novel was the focus for a general critique of American society, and Uncle Tom became a household name, regularly referred to in Italy's illustrated magazines, academic treaties on slavery, and in more general writings on the United States. ${ }^{37}$ When in 1858 Bianchi e Neri was first performed in Turin, the reviewer for L'Italia Musicale informed readers that "the ballet is nothing other than La Capanna dello Zio Tom," assuming that readers knew the book..$^{38}$ The Italian reception of the novel set the scene for subsequent coverage of the Civil War. Along with general consternation over the brutality of the bloodshed, in the context of

${ }^{35}$ Note by Walter Toscanini in NYPL, WTC, LdB, no. 809. The bibliophile, collector, and ballet scholar Walter Toscanini was the son of the conductor Arturo Toscanini and husband of the famous dancer Cia Fornaroli. Marian Eames, When All the World Was Dancing: Rare and Curious Books from the Cia Fornaroli Collection (New York, 1957). On the uses of the Marseillaise, see Axel Körner, Das Lied von einer anderen Welt: Kulturelle Praxis im französischen und deutschen Arbeitermilieu, 1840-1890 (Frankfurt, 1997).

${ }^{36}$ Kohn, Meer, and Todd, "Reading Stowe," xi.

${ }^{37}$ For an assessment of press reactions to the novel, see Frederick H. Jackson, "Uncle Tom's Cabin in Italy," Symposium 7 (1953): 323-32, and Rossi, "Uncle Tom's Cabin and Protestantism in Italy," 419. Long after the novel's first publication the Italian press continued to write about Stowe. See, e.g., L'Universo Illustrato 1, no. 23 (March 1867): 303. For references to Stowe in academic treaties on slavery, see Luigi Cibrario, Della Schiavitù e del servaggio e specialmente dei servi agricoltori (Milan, 1868), 1:326.

${ }^{38}$ L'Italia Musicale, January 4, 1858. 
Italy's recent Unification the excesses of the Civil War seemed to confirm both the impracticality of federalism, which for a long time had been discussed as a possible solution to Italy's own constitutional problems, and the need to control a disparate country from the center through military force. As Raymond Grew has argued, "a nation torn by civil war was an awkward model of federalism; and the newspaper of the Italian National Society warned that federalism had proved to be the American Union's "germ of death." ${ }^{39}$

The first Italian translation of Uncle Tom appeared in the year of the original American publication, 1852, only a year before Rota's ballet. ${ }^{40}$ Within a few months various cheap editions of the novel were available in all the capital cities of the peninsula, with the noticeable exception of Rome, where the Papal censors were concerned about the book's positive depiction of Quakers and Methodists, and the fact that all over the world Stowe was praised as a Protestant hero. ${ }^{41}$ Another Italian translation was published the following year in Switzerland, and a further version appeared in $1898 .{ }^{42}$ Both Il Mediterraneo in Genoa and Il Risorgimento in Turin serialized the novel. Censorship permitting, the Turin papers were especially widely read all over Italy. ${ }^{43}$ The fact that in 1858, for the second round of stagings, Rota's ballet was performed as La Capanna di Tom, making direct reference to the novel's title, suggests that the book was by then widely known. Still, at times it must have been difficult getting hold of the book, and copies were passed on between families. The penal reformer and moderate member of parliament for Parma Giovanni Minghelli Vaini borrowed a copy from Verdi's wife, Giuseppina Strepponi, whose own interest was sparked by the fact that Verdi's new opera, Una ballo in maschera, was often staged together with Bianchi e Neri. ${ }^{44}$

The transnational development of the book trade should not lead one to make assumptions about the homogeneity of the novel's reception on both sides of the Atlantic. There existed more than just one Uncle Tom in the minds

${ }^{39}$ Quoted in Raymond Grew, "One Nation Barely Visible: The United States as Seen by Nineteenth-Century Italy's Liberal Leaders," in The American Constitution as a Symbol and Reality for Italy, ed. Emiliana P. Noether (Lewiston, NY, 1989), 119-34, 121.

${ }^{40}$ La capanna dello zio Tomaso o la schiavitù, Nuovissimo romanzo di Enrichetta Beecher Stowe, 4 vols. (Milan, 1852).

${ }^{41}$ Rossi, "Uncle Tom's Cabin and Protestantism in Italy," 418, 421-22.

${ }^{42}$ La capanna dello zio Tommaso ossia La vita dei negri in America (Lugano, 1853); La Capanna dello zio Tom. Raconto di Enrichetta Beecher Stowe. Nuova Versione (Milan, 1898).

${ }^{43}$ Robert Forrest Wilson, Crusader in Crinoline: The Life of Harriet Beecher Stowe (1941; Westport, CT, 1972), 329.

${ }^{44}$ Minghelli Vaini to Verdi, 09/01/61, in Gaetano Cesari and Alessandro Luzio, eds., I Copialettere di Giuseppe Verdi (Milan, 1913), 587. 
of the novel's readers..$^{45}$ Moreover, we cannot take it for granted that Stowe's book had a direct impact on societal ideas and political events-along the lines of Lincoln's dictum that the Civil War was indeed Mrs. Stowe's war. Instead, the historian must investigate the specific political messages that readers in different parts of the world took from the novel, leading to the question of why Uncle Tom's story had an impact at all. ${ }^{46}$ The fact that the novel was adapted for the stage indicates its popularity, but tells us little about the ways in which it was read. If the "crossracial recognition of virtue" 47 was at the core of the story for American audiences (Mrs. Shelby weeping with Tom's family; or Eva, the white, and Tom, the black, both dying as a consequence of slavery), this was not necessarily the case for Italians, who did not have direct exposure to racial diversity. If Toni Morrison shows how stories such as Uncle Tom helped "reveal the meaning of whiteness," for Italians the novel was mostly a way to learn about America in general. One has to look at what readers knew about its subject, beyond the text of the novel or the libretto itself, in order to reconstruct Uncle Tom's possible impact.

The preface to the Italian translation includes a detailed commentary by the French critic Jean Lemoine that discusses the problem of slavery and points readers to the role that women like Stowe played in public debates on this issue. As with the American and English editions, the Italian version also presents the story of Uncle Tom as more than just a piece of compassionate literature. It was this kind of information, rather than the plot itself, to which the press often referred, including in reviews of the ballet. Stowe's own "key" to the novel was translated as a two-volume commentary on Uncle Tom's Cabin and published in Italy in 1853; it reconstructed the facts on which her work was based and helped Italians to contextualize the work within wider political developments in the United States. ${ }^{49}$ For Italians the "key" opened a window on a largely foreign society, which was perceived to be profoundly different from anything known on the Italian peninsula. While we have no figures for how many Italians read the "key," literary critics who wrote about Stowe regularly referred to the factual information it offered and used it in reviews of the novel and of the ballet. The detailed and well-documented volumes of the "key" offered proof that the novel was more than a piece of fiction and that it delivered an authentic image of American society. With its "oral histories," its rich quotations from original documents, correspondence,

${ }^{45}$ Beniamino Placido, Le Due Schiavitù: Per un'analisi dell'immiganizaione americana (Turin, 1975), 7.

${ }^{46}$ Ibid., 9.

${ }^{47}$ Williams, Playing the Race Card, 47-48.

48 Ibid., 70.

${ }^{49}$ La chiave della capanna dello zio Tomaso contenente $i$ fatti e $i$ documenti originali sopra cui è fonadato il romanzo colle note giustificative (Milan, 1853). 
legislation, and newspapers, the Chiave became one of the first socialanthropological studies of American life accessible to Italian readers in their own language. ${ }^{50}$

The novel itself also made it sufficiently clear that the story constituted an authentic account of life in America. In the last chapter of the final volume, Stowe explains the background to the plot, which was based on a careful character study of people living in a slaveholder society either as victims or as perpetrators. Referring to the original description of the person who became the model for the slave trader Legree, her postface underlines once more the barbarity of the slave economy: "He actually made me feel his fist, which was like a blacksmith's hammer, or a nodule of iron, telling me that it was calloused with knocking down niggers." Situating the narrative in a realistic account of life in the United States, she continues that "this injustice is an inherent one in the slave system,- -it cannot exist without it." ${ }^{51}$ For anybody not used to debates over the experience of slavery, as would be the case for the majority of Italian readers, the consequences of the slave trade for the individuals involved were almost inconceivable:

The writer has given only a faint shadow, a dim picture, of the anguish and despair that are, at this very moment, riving thousands of hearts, shattering thousands of families, and driving a helpless and sensitive race to frenzy and despair. There are those living who know the mothers whom this accursed traffic has driven to the murder of their children; and themselves seeking in death a shelter from woes more dreaded than death. Nothing of tragedy can be written, can be spoken, can be conceived, that equals the frightful reality of scenes daily and hourly acting on our shores, beneath the shadow of American law, and the shadow of the cross of Christ. ${ }^{52}$

The fact that these passages are included in foreign translations of the novel is important because it suggests that Uncle Tom could not be read as mere fiction, not even in countries that were at the time largely unaffected by political or religious debates over slavery. The documentary passages of the novel had an especially important impact on the construction of an image of America in Italy because, compared to Britain or France, economic and

${ }^{50}$ Another book about the United States which by that time was widely read among Italians was the 1856 edition of Carlo Botta's Storia della guerra dell indipendenza degli Stati Uniti d'America (Florence, 1856). Originally published in 1809, the new edition in two handy volumes made the work more widely accessible. However, unlike Stowe (and apart from descriptions of landscape), Botta offered little insight into contemporary life in America, concentrating his narrative on military events and leaders during the War of Independence.

${ }^{51}$ La capanna dello zio Tomaso o la schiavitù, Nuovissimo romanzo di Enrichetta Beecher Stowe, 4 vols. (Milano, 1852), 4:192; quoted after the American edition of Harriet Beecher Stowe, Uncle Tom's Cabin (New York, 2003), 506.

52 Ibid., 197-98 (American ed., 509). 
diplomatic relations with the United States still played only a minor role, with the consequence that the circulation of information about the United States was limited. Also, emigration from Italy to the United States presented only a subsidiary phenomenon until the turn of the century: at the time, the preferred destinations for Italian emigrants were other countries in Europe or Brazil and Argentina. ${ }^{53}$ Compared to Britain, which maintained a close relationship with the United States and a wide range of information readily available via periodicals, in Italy Uncle Tom played a comparatively more important role in the construction of an image of the United States because it represented a rare example of detailed documentation at a time when America was still terra incognita for many Italians.

Loosely based on selected scenes of the novel, Rota's ballet underlines the story's exotic aspect through the introduction of allegorical scenes that are not to be found in the original novel..$^{54}$ During the prelude to the ballet, nature deposits on earth two children, one white, one black, reminding both of them that they are brothers. Anger leads the white boy to suppress the black, subsequently making him his slave. In the original version (1853), the first scene that follows features a party at the house of Thompson, the English envoy to Washington, who is a member of a society for the emancipation of

${ }^{53}$ The United States established diplomatic relations with the Kingdom of the Two Sicilies in 1816, with Sardinia in 1840, and with the Papal States in 1848. After the execution of the patriotic priest Ugo Bassi in August 1849, the Pontiff's legate to the United States was expulsed. Roland Sarti, "La democrazia radicale: Uno sguardo reciproco tra Stati Uniti e Italia," in La democrazia radicale nell'ottocento europeo, ed. Maurizio Ridolfi (Annali Fondazione Giangiacomo Feltrinelli, 39) (Milan, 2005), $133-57,137,144-45$. During the decade $1861-70$ only 21,768 Italians migrated to a non-European country, compared to 99,272 Italians who migrated within Europe. In the decade 1881-90, 24,487 immigrated to the United States, but more than twice as many preferred Argentina or Brazil as their country of destination. The huge wave of migration to the United States started only during the first decade of the twentieth century, with a total number of 232,945. Istituto Centrale di Statistica, Sommario di Statistiche Storiche dell'Italia, 1861-1975 (Rome, 1976), 34-35. For a general overview, see Anna Maria Martellone, "Italian Mass Emigration to the United States, 1876-1930: A Historical Survey," Perspectives in American History 1 (1984): 379423. On the preference for countries other than the United States, see also Maria Giovanna Pierattini, "Vien via, si va in America, si parte": Un secolo di emigrazione pistoiese; Storia e storie, itinerari e mestieri (Pistoia, 2002), 59.

${ }^{54}$ This summary synthesizes the following version of the libretto: I Bianchi ed $i$ negri. Azione storica-allegorica in tre quadri e sette scene del coreografo Giuseppe Rota. Riprodotta dal Coreografo Ferdinando Pratesi nel Regio Teatro della Scala nell autunno 1863. Milan: Luigi di Giacomo Pirola (NYPL, WTC, LdB, no. 809). The original version staged in Milan in 1853 is similar to that presented in Bologna in 1858 and in Milan in 1863. The versions presented in Rome in 1858 and in Turin in 1875 contain further variations. As was the case for opera, it was common that individual theaters would add or cut parts of a work, according to the disposition and the requests of local artists. See, e.g., L'Arpa, October 18, 1858. 
Negroes. Unexpectedly, the fugitive slave George enters the room. He had been freed by Thompson and now hopes to liberate those who still share his former fate as slaves. Humanity provides George with guidance in the form of a book, the Code of Truth. In the second scene, George starts his mission on Legree's plantation, offering himself to the master as a new supervisor for his slaves. Legree makes indecent advances to the slave Dellay, but is interrupted by the arrival of his daughter, Angelina. In order to break Dellay's resistance and isolate her from her family, Legree decides to sell her father (Uncle Tom), her husband (Sab), and their young son (Henry) to the slave trader Christie. Angelina promises to protect the family from her father's evil intentions. Next, Legree discovers Dellay's husband, Sab, with a book and punishes him for intending to instruct himself. When Legree makes another attempt to conquer Dellay, Sab intervenes. Legree orders George to beat him. George refuses and is made to leave. Legree sells the three male members of the family to Christie. While Tom obeys, the rest of the family decide to escape. In the fourth scene, the family is hiding at the property of the merchant Gordon, whose life Sab had once saved. For a sum of money Gordon reveals the hiding place to Christie. While George helps Dellay and Henry to escape, Sab is caught in a fight. When he shoots Gordon he is arrested. In the penultimate scene, George convinces the incarcerated slaves to pray for God's help. When Legree enters the prison to retrieve his slaves they suddenly find the strength to oppose him. The ballet concludes with another allegorical scene, set in the Temple of Truth, where the Genius of Humanity ends centuries of racial division and unites blacks and whites forevermore.

Every libretto is no more than a loose adaptation of its literary source. While ballet makes it almost impossible to represent the narrative structure of a novel closely, Rota's allegorical scenes at the start and the end of the ballet serve the purpose of integrating the humanist intentions and religious motives of Stowe's novel. The fact that some of the ballet's first reviews criticized Rota for these additions to the novel's narrative demonstrates how closely audiences and critics associated the ballet with the novel. ${ }^{55}$ In his libro $d a$ ballo, Rota decided to conflate scenes from the two narratives of Stowe's novel: the story of Eliza (becoming Dellay in the ballet), heading north for freedom, and the story of Tom, sold south and dying under even more terrible conditions. There are some important variations between the different stagings of the ballet. In the 1858 version Angelina becomes Erichetta, a name read as

${ }^{55}$ La Fama del 1853: Rassegna di Scienze, Lettere, Arti, Industria e Teatri, November 14, 1853. L'Italia Musicale, January 4, 1858, opined that the literary source did not adapt itself to ballet. Much more positive was Il Trovatore: Giornale Letterario, Artistico, Teatrale, January 6, 1858. The caricatures reproduced in the issue of January 20, 1858, do not seem to criticize Rota's ballet but the management of Turin's Teatro Regio and the simultaneous performance of Rigoletto. 
an Italian version of Harriet. In the later stagings the Book of Truth of the 1853 version becomes the Bible. Uncle Tom himself plays a secondary role in all versions, but the novel also refers to him only in some sections. Despite these alterations to the plot, the choreography takes up many central elements of the novel, on which Stowe also commented in the "key": the devastation of family structures as a consequence of the slave trade, the sexual implications of the relationship between the master and his female slaves, the physical brutality of slaveholders and traders, the role of education and religion in the life of slaves. It is these themes that allowed Italians to catch up with the debates in countries like Britain, where over the past decades abolition had played a more important public role. In addition to commenting on general issues of the novel's adaptation and on the choreography itself, most reviews of the ballet go into detail in describing the narrative's sad and brutal content. ${ }^{56}$

Stowe became a star in Italy and was well known beyond circles of educated Italians. Visiting Rome in 1857, she would have disturbed those Americans in Rome who held Southern sympathies, but she certainly found admirers among the Italian people. Visiting the Castellani sculpture workshop and observing one of the two brothers carving the head of an Egyptian slave in onyx, she was recognized and greeted with the words: "Madam, we know what you have been to the poor slave. We ourselves are but poor slaves still in Italy; you feel for us; will you keep this gem as a slight recognition for what you have done?"57 As inappropriate as the comparison between American slaves and Italians in the Papal States might seem, one of the reasons for Uncle Tom's popularity was the fact that Italians were able to compare their own fate to that of the oppressed slaves. Stowe was read and discussed in the context of general humanitarian concerns and ideas of liberation. In 1859, on her second visit to Italy, Stowe attended the meeting of the Tuscan Assembly at which the adherence of Tuscany to Piedmont was declared, which subsequently gave rise to the Unification of Italy ${ }^{58}$ - clearly a symbol of connections between Uncle Tom and the liberation of Italy.

Despite the novel's role in Italian debates on America, certainly one should not overemphasize possible political readings of the ballet. In many respects the production fit in perfectly with the choreographer's more general interest

${ }^{56}$ See in particular L'Arpa, October 18, 1858. The more critical reviews had less to do with the ballet's content than with the performance of individual dancers.

${ }^{57}$ Quoted in Van Wyck Brooks, The Dream of Arcadia: American Writers and Artists in Italy, 1760-1915 (New York, 1958), 129. On her visit to Italy, see also Nathalia Wright, American Novelists in Italy. The Discoverers: Allston to James (Philadelphia, 1965), 87-89, although the author's discussion of Stowe's evaluation of the Catholic Church seems questionable.

${ }^{58}$ Wright, American Novelists in Italy, 88-89. 
in foreign and exotic topics. ${ }^{59}$ Moreover, when Rota presented his Bianchi e Neri slavery was not a new topic for the stage, at least if one includes the representation of slaves in the orientalizing genre of ballet and opera. Here slavery usually served to depict despotism and cruelty within cultures described as uncivilized or unenlightened, often in the form of humorist parody for the carnival season. ${ }^{60}$ Intellectually, the association between slavery and oscurantismo reflected Montesquieu's belief that it had been Christianity that led to the abolition of slavery in Europe, despite the fact that other enlightened philosophers, such as the Abbé Raynal, were fully aware that the discovery of the New World was intrinsically linked to the beginning of the transatlantic slave trade. ${ }^{61}$ However, by the time that nineteenth-century Italian ballets discussed slavery, even in most countries of the New World the problem had disappeared, with the notable exceptions of Cuba, Brazil-and the United States.

In addition to his Uncle Tom ballet, Giuseppe Rota treated slavery in several other pieces, for instance, in his Indian Elda e Dielma at the Roman Apollo Theater in $1861 .{ }^{62}$ Probably the most spectacular example contrasting slavery and civilization on stage was Luigi Manzotti's ballet Excelsior, which premiered in Milan in 1881 and employed more than five hundred dancers. ${ }^{63}$ Although by that time even the United States had ended slavery and was represented through images of the Brooklyn Bridge as a force of progress,

${ }^{59}$ In 1862 Rota presented a Chinese ballet at the Pergola in Florence, Lo spirito maligno, NYPL, WTC, LdB, no. 799.

${ }^{60}$ During the carnival of 1867 the famous choreographer Paolo Taglioni presented the ballet Thea o la Fata dei Fiori at La Scala, featuring slaves from Africa and the Near East. NYPL, WTC, LdB, no. 868. A few years later both La Scala and the Regio in Turin staged Pasquale Borri's Nephte o il figliol prodigo, also including Arab and African slaves. NYPL, WTC, LdB, no. 883 (Turin, 1869), no. 923 (Milan, 1873). In many of these pieces slavery was presented as an aspect of Orientalism. Paul Gilroy argues that slavery was at the center of the Enlightenment debates on the concept of modernity: The Black Atlantic: Modernity and Double Consciousness (Cambridge, MA, 1993).

${ }^{61}$ David Brion Davis, The Problem of Slavery in Western Culture (1966) (Oxford, 1988), 14-15. A powerful and widely circulated example of the Enlightenment view on slavery is also provided by Voltaire's Candide.

${ }^{62}$ Elda e Dielma, Apollo Theater, Rome, in 1861, featuring slaves in India: NYPL, WTC, LdB, no. 787. See also Antonio Pallerini's L'Anello infernale ossia Folgore: Ballo fantastico in sei parti, set in Cadice during the sixteenth century and performed at La Scala during the autumn of 1862: NYPL, WTC, LdB, no. 795.

${ }^{63}$ Luigi Manzotti, Excelsior (Milan, 1881); Carol Lee, Ballet in Western Culture: A History of Its Origins and Evolution (New York, 2002), 176; "Excelsior," in The Encyclopedia of Dance and Ballet, ed. Mary Clarke and David Vaughan (London, 1977), 134; Alberto Testa, Storia della danza e del balletto (Rome, 1994), 78; Jutta Toelle, Bühne der Stadt: Mailand und das Teatro della Scala zwischen Risorgimento und Fin-De-Siècle (Vienna, 2009), 120-22. 
Manzotti still refers the spectator back to the theme of Rota's Bianchi e Neri, first staged almost thirty years earlier. One of the images in Excelsior describes the opening of the Suez Canal, presenting Suez as a brotherhood of peoples, a land of utopian promise for all races living together under the authority of the Khedive. ${ }^{64}$ Through Verdi's Aida, premiered ten years earlier in Cairo in connection with the opening of the canal, Italians could easily engage with the setting. Central to Manzotti's scene is the liberation of the slaves (scene 8), presented in the form of a pas de deux featuring "Civilisation" and "the Slave." 65 The similarity to Rota's pas de deux in Bianchi e Neri, together with the fact that Rota and Manzotti were known for having worked together closely on a number of productions, suggests that audiences made a connection between the two works. In the context of any ballet the pas de deux was of central importance, and it was usually anticipated impatiently by the audience, making it the focal point of the work. The slave in Excelsior, with his extravagant jumps, became the star of the ballet. Excelsior soon conquered all the major theaters of the world. Its first staging in 1881 reached a total of 103 performances, followed by productions at the San Carlo, the Regio in Turin, Trieste, Bologna, the Politeama in Florence, as well as stagings in both Americas (with 100 performances at Niblo's Garden in New York), at the Victoria in Berlin, the Zarzuela in Madrid, as well as at the Eden in Paris, where the 300 performances made a profit of 2,100,000 francs. ${ }^{66}$ The two most important Italian choreographers of the nineteenth century, Rota and Manzotti, made their names through stagings that featured the end of slavery.

Theater continued to influence Italians' ideas of the New World. Musical representations of America included, among the more famous works, Donizetti's cantata Cristoforo Colombo o sia la scoperta dell'America, Verdi's Un ballo, mentioned above, and Franchetti's Cristoforo Colombo. ${ }^{67}$ Travel and

${ }^{64}$ Claudia Celli, "Manzotti and the Theatre of Memory of the Nineteenth Century," in Excelsior: Documenti e Saggi, ed. Flavia Pappacena (Rome, 1998), 209-26, 221.

${ }^{65}$ Flavia Pappacena questions the ideological and political importance of the abolition scene in Excelsior, which also served as a pretext to introduce the obligatory pas de deux into a narrative otherwise dominated by mass scenes: ibid., "An analysis of the Ballet Structure," 269-81, 271-72.

${ }^{66}$ Flavia Pappacena, "The Transcription of the Ballet Excelsior and the Manuscript of the Theatre Museum at La Scala," in Pappacena, ed., Excelsior, 249-68, 249. Stagings abroad were usually produced by local directors and adapted with local sets.

${ }^{67}$ Paologiovanni Maione and Francesca Seller, "Cristoforo Colombo o sia la scoperta dell'America di Donizetti," Studi Musicali 34 (2005): 2, 421-49. For an overview of operas on the discovery of the New World, see Thomas F. Heck, "Toward a Bibliography of Operas on Columbus," Notes 49, no. 2 (December 1992): 474-97; see also his "The Operatic Christopher Columbus: Three Hundred Years of Musical Mythology," Annali d'italianistica 10 (1992): 236-78. The most important work on representations of America in Italian opera is Pierpaolo Polzonetti, Italian Opera in the Age of the American Revolution (Cambridge, 2011). For a general overview, see 
discovery also provided popular topics in ballet. ${ }^{68}$ The composer of Bianchi e Neri, Paolo Giorza, established himself as an expert on the American theme: a few years after Bianchi e Neri he composed the music for Monplaisir's Colombo, a real hit on the Italian stages. ${ }^{69}$ In these exotic ballets America was not just a new but a different world, treated in a rather monolithic fashion and often emphasizing its natural otherness. The enlightened humanism of Western civilization contrasts with the character of the bon savage in the New World or the despotism of noncivilized peoples. Reading Bianchi e Neri within the context and the history of this genre, it is striking that in staged representations the United States is portrayed as lacking the values and the culture that characterized the Europe of the Enlightenment. What Stowe's America seemed to represent was a particularly brutalized form of what until now had characterized non-European societies.

It is exactly this aspect-slavery contradicting the ideals of civilization and progress - that references to the United States in the reviews of Bianchi e Neri underline. On the occasion of the ballet's 1863 revival, the Milanese literary journal La Fama describes William Wilberforce's early nineteenth-century movement against the transatlantic slave trade. It had been widely assumed that the "trade of human flesh" would disappear from the globe as a consequence of the movement's success: "Unfortunately, one did not consider the indomitable tenacity of the Anglo-Saxon race in the Southern United States. They are united around an antisocial principle, based on the pure reason of force: that the white man owns the black, a principle sanctioned by laws,

Jürgen Maehder, "The Representation of the Discovery on the Opera Stage," in Musical Repercussions of 1492, ed. Carol E. Robertson (Washington, DC, 1992), 257-83; Franchetti's Cristoforo Colombo, on a libretto by Luigi Illica, was commissioned by the city of Genoa and premiered under Mancinelli in 1892, followed by presentations in Treviso and at Bologna's Comunale under Toscanini. For contemporary pictorial representations see, e.g., Palagio Palagi's Columbus scenes in Claudio Poppi, ed., L'ombra di core: Disegni dal fondo Palagi della Biblioteca dell'Archiginasio (Bologna, 1989), 37-39; probably more influential was the monument by Vincenzo Vela ("Colombo e l'America") for the World Exhibition of 1867, presenting Columbus generously protecting a female Native American nude: see illustration in L'Universo Illustrato 2, no. 8 (November 1867): 129-30.

${ }^{68}$ For American themes in ballet, see also Raimondo Fidanza's Colombo, ossia La Scoperta del Nuovo Mondo (Genoa, 1802); Cohen, "Feme di Gelosia!" 558; Colombo all'isola di Cuba, azione mimica di mezzo carattere in Quattro parti di Antonio Monticini, represented at La Scala in the autumn 1832 and again at the Regio in Turin in 1838: NYPL, WTC, LdB, nos. 332 and 431.

${ }^{69}$ NYPL, WTC, LdB, no. 819. Along with Colombo and his celebrated ballet Brahma, Ippolito Monplaisir created L'Isola degli Amori, a ballo fantastico about Vasco da Gama, performed in 1861 at La Scala in Milan as well as the Teatro Apollo in Rome. NYPL, WTC, LdB, nos. 785 and 793. 
which treat these men as simple objects, to be exploited and commercialized like wild beasts." ${ }^{\prime 70}$ Not only is it remarkable that the review of a ballet would engage in debates about this wider historical and social context of slavery; the author also presents his readers with a condemning judgment on U.S. society. The article goes on to outline the implications of slavery for the United States' constitutional system, leading to the causes of the current Civil War, "the most horrible massacre in the history of humankind." ${ }^{\prime 11}$ In Italy the review of a ballet could cover wide territory.

\section{Two UnIFICATIONS}

When Bianchi e Neri first toured Italy in the 1850s, slavery represented only one image among many that Italians associated with America. These images were largely determined by the particular circumstances and the perspective of the observer. For instance, the American War of Independence almost coincided with the awakening of national sentiment in Italy, leading later generations of Italian patriots to look across the Atlantic for lessons. ${ }^{72}$ When in the middle of the following century Stowe pointed to the Christian motives behind the fight for abolition, this seemed to confirm that freedom of religion, as practiced in the United States, encouraged political liberation. This could not go unnoticed in Italy, where until 1848 popular religion played an important role in creating a mass basis for the national movement. Meanwhile, national liberation was also understood as liberation from Papal dominion and as the end of a theocratic system of government. As a matter of fact, in 1863 the Republican almanac L'amico di casa saw no difference "between Jews in the Papal States and Negroes in America." ${ }^{3}$ Apart from her admiration for the Catholic Church's symbolism and its spirituality, Stowe echoed the condemnations by Italian patriots of the Church's tyranny and made the Pope's "perverted religion" the topic of another, less known novel, Agnes of Sorrento. ${ }^{74}$ Italian

${ }^{70}$ La Fama del 1863, September 29, 1863.

${ }^{71}$ Ibid.

${ }^{72}$ Botta's History of the War of the Independence is certainly of interest here, but certain claims regarding these connections need further investigation. See, in this context, Carlo Dionisotti, Vita di Carlo Botta (Turin, 1867); Jordan D. Fioere, "Carlo Botta: An Italian Historian of the American Revolution," Italica 28, no. 3 (September 1951): 155-71; more recently Luciano Canfora and Ugo Cardinale, eds., Il Giacobino Pentito: Carlo Botta fra Napoleone e Washington (Rome, 2010).

${ }^{73}$ L'Amico di Casa: Almanacco Popolare Illustrato. 1863 (Turin, 1862).

${ }^{74}$ The novel was written in the winter of 1859-60 during her second visit to Italy. During the trip she visited Florence, Rome, and Naples, as well as Como, Milan, Verona, and Venice. William L. Vance, America's Rome (New Haven, CT, 1989), 2:22; Wright, American Novelists in Italy, 88, 90-103. On the Catholic reaction to Uncle Tom, see Rossi, "Uncle Tom's Cabin and Protestantism in Italy." 
anticlericals found a willing supporter in the first American minister to the Kingdom of Italy, George Perkins Marsh, who "indulged in anti-Papal diatribes" and regarded the Catholic Church as an institutionalization of "tyranny, reaction and superstition." 75 Meanwhile, the narrative of a "racialized Christlike passion," "76 with the devout Uncle Tom being beaten to death by his master, responded to a religious sentiment that was also shared by many Italian anticlericals. All this facilitated the Italian response to Stowe's mission and to Uncle Tom in particular.

As can be seen from reactions to Uncle Tom and to Bianchi e Neri, the relationship between the Risorgimento and the United States went beyond widespread admiration for America's practice of religious freedom. The United States had been a mecca for European exiles not just after 1848 but as early as 1835 when, on his accession to the Austrian throne, Ferdinand I had issued an imperial rescript granting to Italian prisoners a commutation of sentence on condition that they agreed to be deported to America. However, while some accepted the condition, others preferred to serve out their sentences in prison. ${ }^{77}$ European revolutionaries knew that public opinion in the United States was not unanimous in its support for their uprisings, that many Americans feared radical socialism and the negative consequences of revolution for their business relations with the old continent. Despite the fact that a number of American envoys to Italy supported the process of Unification, officially the government of the United States adopted a policy of strict neutrality. ${ }^{78}$ Catholic Americans condemned Italian patriots for their treatment of the Pope. ${ }^{79}$ Despite the fact that Garibaldi's arrival in the United States had

${ }^{75}$ Mary Philip Trauth, Italo-American Diplomatic Relations, 1861-1882: The Mission of George Perkins Marsh, First American Minister to the Kingdom of Italy (Washington, DC, 1958), xv; David Lowenthal, George Perkins Marsh: Versatile Vermonter (New York, 1958).

${ }^{76}$ Williams, Playing the Race Card, 47.

${ }^{77}$ Rossi, The Image of America in Mazzini's Writings, 13; Marco Sioli, "Se non c'è il conquibus si muore come cani: Luigi Tinelli a New York (1851-1873)," in Fiorentini and Sanfilippo, eds., Gli Stati Uniti e l'Unità d'Italia, 141-50, 141.

${ }^{78}$ Daniele Fiorentino, "La politica estera degli Stati Uniti e l'unità d'Italia," in Fiorentini and Sanfilippo, eds, Gli Stati Uniti e l'Unità d'Italia, 45-81. See also Riall, Garibaldi, 113, 166. When Americans supported the Risorgimento it was often not out of idealism but anticipating future economic benefits from a potential market for American products. See Paola Gemme, Domesticating Foreign Struggles: The Italian Risorgimento and Antebellum American Identity (Athens, GA, 2005), 6.

${ }^{79}$ Giuseppe Monsagrati, "Gli intellettuali americani e il processo di unificazione italiana," in Fiorentini and Sanfilippo, eds., Gli Stati Uniti e l'Unità d'Italia, 17-44, 18; Vance, America's Rome, 2:122-24, 129. See also Leonardo Buonomo, Backward Glances: Exploring Italy, Reinterpreting America (1831-1866) (Teaneck, NJ, 1996), as well as the essays in Robert K. Martin and Leland S. Person, eds., Roman Holidays: American Writers and Artists in Nineteenth-Century Italy (Iowa City, 2002). 
been greeted with a great deal of anticipation, and he was frequently compared to General Washington, widely read accounts of his life did not present a rosy picture of his experiences in the United States. ${ }^{80}$ One of the first Italian novels of emigration, published by the Mazzinian Antonio Caccia just after 1848, presented the unpleasant image of an American nativist who resented "the daily arrival of hungry Europeans." 81 Much of this was known to Italian observers and influenced the construction of a rather ambivalent image of the United States.

For some Italians the United States' federal constitution seemed to offer a blueprint for political Unification. ${ }^{82}$ However, even the federalist Carlo Cattaneo was aware of differences in political traditions and geopolitical circumstances between the New and the Old World and often looked for federal models elsewhere, in Switzerland or in Italy's own history ${ }^{83}$ For others there was something fundamentally wrong with the American understanding of

${ }^{80}$ The fact that he is so very brief on his period in New York speaks for itself. Giuseppe Garibaldi, Memorie Autobiografiche (Florence, 1888), 264 ff.; Jessie White Mario, Garibaldi e i suoi tempi (Milan, 1884), 364-65. See also Lucy Riall, Garibaldi: Invention of a Hero (New Haven, CT, 2007), 107 ff.; Alfonso Scirocco, Garibaldi: Citizen of the World (Princeton, NJ, 2007), 192, 193. For comparisons between Garibaldi and Washington, see Francesco Bertolini, Garibaldi e la nuova Italia (Naples, 1882), 6, 9. For further examples, see also Dennis Mack Smith, Garibaldi (London, 1957), 69.

${ }^{81}$ Antonio Caccia, Europa ed America (1850). The two protagonists of the novel were surprised how little interest Americans had in their revolution. Emilio Franzina, Dall'Arcadia in America: Attività letteraria ed emigrazione transoceanica in Italia (Turin, 1996), 43. On criminalizing southern Italians in America, see also Anthony V. Margavio, "The Reaction of the Press to the Italian-American in New Orleans, 1880-1920," Italian Americana 4, no. 1 (Fall/Winter 1978): 72-83.

${ }^{82}$ Sarti, "La democrazia radicale," 137. See also Pierangelo Schiera, "Centralismo e federalismo nell'unificazione statal-nazionale italiana e tedesca," in Centralismo e federalismo tra Otto e Novecento: Italia e Germania a confronto, ed. Oliver Janz, Pierangelo Schiera, and Hannes Siegrist (Bologna, 1997), 21-46; Marco Meriggi, "Centralismo e federalismo in Italia: Le aspettative preunitarie," in ibid., 49-63; Ernesto Ragionieri, Politica e amministrazione nella storia dell'Italia unita (Rome, 1979), 97; Don H. Doyle, Nations Divided: America, Italy, and the Southern Question (Athens, GA, 2002), 29; Maurizio Isabella, Risorgimento in Exile: Italian Émigrés and the Liberal International in the Post-Napoleonic Era (Oxford, 2009), 60-62. In the context of these debates the Italian reception of de Tocqueville obviously played a role, even if after 1849 he was widely perceived as the French foreign minister responsible for the end of the Roman Republic. Maurizio Ridolfo, "La Démocratie en Amérique di Tocqueville e la sua ricezione nell'Italia del Risorgimento," in Fiorentini and Sanfilippo, eds., Gli Stati Uniti e l'Unità d'Italia, 133-39.

${ }^{83}$ The most important study on this topic is Filippo Sabetti, "Cattaneo e il modello americano: Per una scienza politica nuova," in Carlo Cattaneo: I temi e le sfide, ed. Arturo Colombo, Franco della Peruta, and Carlo G. Lacaita (Milan, 2004), 345-66; also Filippo Sabetti, Civilization and Self-Government: The Political Thought of Carlo Cattaneo (Lanham, MD, 2010). 
freedom. Mazzini criticized America's republican thought for stifling "the principle of association under the omnipotence of the individual ... and enthron[ing] selfish interests and materialism." With reference to the United States' federal constitution, in 1838 he confessed his "cordial antipathy for the very name of that country." ${ }^{44}$ Mazzini considered the federal model a great risk for the future of his movement, favoring instead the Republican centralism of the French revolutionary tradition. ${ }^{85}$ The Italian reviews of Rota's ballet pointed to the fact that it was federalism that enabled American slaveholders to oppose abolition. ${ }^{86}$ The Civil War proved those voices that had questioned the practicality of federalism altogether to be right.

These constitutional debates notwithstanding, and even after Unification, for a surprisingly large number of Italians America did not mean much at all or was simply a nonentity. As Leonardo Buonomo has pointed out, "its citizens were commonly called inglesi [English], a frequent cause of irritation for U.S. travelers and an actual disadvantage: among all foreign visitors of Italy, the least popular were precisely those from England." 87 Even Italians who were well read in political geography, like Carlo Cattaneo, included the American people among the stirpe britannica, and Prime Minister Baron Bettino Ricasoli spoke about the "glory of the razza Anglo-Sassone in the two hemispheres." 88 For many Italians the distinction between the United States and South America was also far from obvious, and frequently one notices their confusion about which territories of the New World actually formed part of the northern Republic. As mentioned earlier, this was also because ideas of America were often based on a very limited acquaintance with literature on the New World. Even a fervent reader such as Mazzini knew hardly more than the works of James Fenimore Cooper. ${ }^{89}$ This changed with the reception of Stowe; and after the American Civil War Italian periodicals started writing in more detail about events and political developments across the Atlantic, presenting a shockingly brutal image of life in the war-torn society.

${ }^{84}$ Quoted in Rossi, The Image of America in Mazzini's Writings, 5, 14. See also Dennis Mack Smith, Italy: A Modern History, new ed. (Ann Arbor, MI, 1969), 13-14. See in this context also the monarchical-federal pamphlet by Alessandro Luigi Bargani, Progetto di costituzione dei Regni Uniti d'Italia offerto ai circoli politici e federativi degli Stati italiani da un cittadino degli Stati Uniti d'America (Turin, 1848).

${ }^{85}$ Rossi, The Image of America in Mazzini's Writings, 6-7; Sarti, "La democrazia radicale," $139,147$.

${ }^{86}$ La Fama del 1863, September 29, 1863.

${ }^{87}$ Buonomo, Backward Glances, 18.

${ }^{88}$ Carlo Cattaneo, "Di alcuni stati moderni" (1842), in Cattaneo, Scritti storici e geografici, ed. Gaetano Salvemini and Ernesto Sestan (Florence, 1957), 1:255-301, 272-73. For Ricasoli: La Nazione, March 29, 1862.

${ }^{89}$ Rossi, The Image of America in Mazzini's Writings, 2-3. On the appeal of Cooper to emigrants from Europe, see also Andrew Rolle, The Immigrant Upraised: Italian Adventurers and Colonists in an Expanding America (Norman, OK, 1968), 26, 59. 
The 1860s were also the years in which novels about emigration as well as about life and travel in America became increasingly popular and were translated into Italian, often transmitting the idea of a rough and uncivilized society. ${ }^{90}$ Although certainly not prejudiced against Americans, Giovanni Capellini, the future rector of Bologna's university, included in his travel account numerous episodes illustrating the contrasting manners of the New and the Old World. He was shocked by the cultural realities of a society that denied the "natural distinction" between social classes. He presented disturbing images of those areas directly affected by the battles of the Civil War. In the hotels where he stayed he had to keep a Colt under his pillow, while mice danced on his blanket and happily ran across his face! ${ }^{91}$ Even for Capellini, a traveler with ample experience of the Italian South, America was hard to take in. While these ambivalent representations of the United States contrasted with the earlier image of the United States as the realization of Enlightenment ideals, they seemed to confirm the brutality alluded to in Stowe's novel and Rota's ballet.

\section{Italian Lessons From the American Civil War}

Lincoln became president of the United States just ten days before Vittorio Emanuele was proclaimed king of Italy; the United States was the first country to recognize the Kingdom of Italy. Despite the recent secession of the Southern states, Americans continued to follow events in Italy, and in January 1861 La Nazione reported on a meeting in New York that brought together more than three thousand people in support of Garibaldi. ${ }^{92}$ Likewise, while Italians had reason enough to concentrate on their own Civil War, they followed the news about the escalating conflict across the Atlantic closely. When Ricasoli voiced his support for the constitutional authorities of the North, he did this also in the awareness of the secessionist ambitions of Papal and Southern legitimists in Italy. However, the Italian response to the American Civil War went beyond a shared concern for the integrity of the nationstate. Because of their close engagement with Stowe and Rota, Italians were able to engage with this conflict on a much more personal and emotional basis, and references to Uncle Tom in general debates about America suggest that

${ }^{90}$ Franzina, Dall'Arcadia in America, 76. Gerstaecker, whose stories also appeared in the periodical press, often presented Americans as uncivilized and bold: L'Universo Illustrato 1, no. 8 (November 1866): 122-24. Italians were particularly taken by Poe's stories, but also by what they knew about his own life: Gustavo Tirinelli, "Edgardo Allan Poe," Nuova Antologia, 2nd ser. 4, no. 4 (April 1877): 731-62.

${ }^{91}$ Giovanni Capellini, Ricordi di un viaggio scientifico nell'America settentrionale nel 1863 (Bologna, 1867), 20-21.

${ }^{92}$ La Nazione, January 10, 1861. See, for similar campaigns, Riall, Garibaldi, 296. 
the reception of the novel played an important part in making American slavery and the Civil War an issue of public concern in Italy.

Many Italian patriots saw their own national Unification and the abolition of slavery in America as "one single cause": a struggle for the good of humankind as a whole. ${ }^{93}$ However, the path toward this insight was not straightforward. Historically, the Italian Democrats had close relations with the Democratic Party in the United States and were hesitant in declaring themselves for Lincoln. Their attitude changed relatively late, only after the Emancipation Declaration. Meanwhile, as an international champion of freedom, Mazzini was popular in American antislavery circles, and his concern over the dangers of the federal system shared common ground with the political intentions of the American Republicans. ${ }^{94}$ Mazzini knew Stowe's family, including her husband, and Henry Ward Beecher, the most famous Congregationalist preacher of his time, supported Italian Republicans in exile, such as Jessie White Mario. Lincoln offered Garibaldi a commission as major general in the Union Army and a Garibaldi Brigade of 350 men, of which about fifty were Italians, fought for the North. Many individual units included experienced Italian officers, among them the later director of the Metropolitan Museum, Luigi Palma di Cesnola. However, there were also about 500 Italians fighting for the South. The American administration itself saw the Redshirts largely as a wild bunch of adventurers seeking American-paid transportation to the New World. ${ }^{95}$ The decision not to recognize the Confederacy, despite the fact that the Italian cotton mills depended on raw material from the South, was one of the few issues on which Italian democrats and moderates were able to agree. ${ }^{96}$ In this respect the policy of the Holy See was less clear; the American South tried to capitalize on the fact that the Pope

${ }_{93}$ Enrico Dal Lago, "Radicalism and Nationalism: Northern 'Liberators' and Southern Labourers in the USA and Italy, 1830-60," in Dal Lago and Rick Halpern, eds., The American South and the Italian Mezzogiorno: Essays in Comparative History (Basingstoke, 2002), 197-214, 197; Sarti, "La democrazia radicale," 145-48; Leopoldo Ramanzini, Una lettera di Garibaldi ad Abramo Lincoln (Vicenza, 1970). Also David A. J. Richards, Italian American: The Racializing of an Ethnic Identity (New York, 1999), 118.

${ }^{94}$ Timothy M. Roberts, "The Relevance of Giuseppe Mazzini's Ideas of Insurgency to the American Slavery Crisis of the 1850s," in Giuseppe Mazzini and the Globalization of Democratic Nationalism, 1830-1920, ed. Christopher A. Bayly and Eugenio F. Biagini (Oxford, 2008), 311-20. In 1872 Lincoln's "esequie ferroviarie" and his embalming became the model for Mazzini's funeral: Sergio Luzzatto, La mummia della repubblica: Storia di Mazzini imbalsamato, 1872-946 (Milan, 2001), 35-36.

${ }^{95}$ Rossi, The Image of America in Mazzini's Writings, 162; Trauth, Italo-American Diplomatic Relations, 8-34. See also Valentino J. Belfiglio, "Italians and the American Civil War," Italian Americana 4, no. 2 (Spring/Summer 1978): 163-75.

${ }_{96}$ Trauth, Italo-American Diplomatic Relations, 1. 
maintained correspondence with the Confederate President, Jefferson Davis. ${ }^{97}$ The Church questioned the legitimacy of the United States on the same basis that it questioned the Kingdom of Italy: "While Italy constitutes itself as one, which it has never been, ... in the United States they dissolve their union, because for some of them unity is such an unbearable condition that a war seems justified." 98 The impact of the Church on the formation of an Italian image of America is not to be neglected. In terms of readership, Civiltà Cattolica was still the peninsula's most influential periodical, and even in Piedmont it had more subscribers than any of the liberal periodicals. ${ }^{99}$ However, even the Church was unable to defend the slave economy in the South. Although not against slavery in principle, it took the view that under the paternal protection of the Church "the master becomes father, and the slave almost a son. But in America things are different: there slavery results in tyranny, a monstrosity." 100 Here, the Church's depictions of slavery did not sound too different from those of Stowe and Rota, despite Rome's earlier opposition to Uncle Tom.

What overshadowed Italy's widespread enthusiasm for the North's cause was the coverage of the Civil War's unimaginable brutality. Italian newspapers were filled with detail describing how the bloodshed penetrated every corner of American society. One of the early Italian commentators on the American Civil War described the conflict as the "devil's war," showing particular concern at the circulation of weapons among the civilian population. ${ }^{101}$ La Nazione used the term "terrorism" to describe the policies of the South, but it also shed doubts on Lincoln's integrity: "for him the negroes are just a means to go to war against the whites." Here, the Italian paper ignored the extent to which abolitionism had become a religiously and politically motivated mass movement in the United States. ${ }^{102}$ Although this sort of attack against the president was rare, the Italian paper almost seemed to echo the personalized campaigns of the pro-Southern members of the British parlia-

${ }^{97}$ For the Catholic Church's ambiguous position, see "Il concetto morale della schiavitù," Civiltà Cattolica (February 1865): 427-45; Donaldson Jordan and Edwin J. Pratt, Europe and the American Civil War (Boston and New York, 1931), 194. Later, however, the Papal States fully collaborated with the prosecution of one of the alleged accomplices to Lincoln's assassination. Trauth, Italo-American Diplomatic Relations, 36. For a recent study of the problem, see Matteo Sanfilippo, L'affermazione del cattolicesimo nel Nord America: Elite, emigranti e chiesa cattolica negli Stati Uniti e in Canada, 1750-1920 (Viterbo, 2003), 97 ff.

98 "La Disunione negli Stati Uniti," Civiltà Cattolica (February 1861): 312-24, 312.

${ }^{99}$ See "La stampa cattolica in Italia," Civiltà Cattolica (January 1865): 43-59, 44.

100 "La Disunione negli Stati Uniti," Civiltà Cattolica (February 1861): 312-24, 322.

${ }^{101}$ Capellini, Ricordi di un viaggio scientifico, 72, 144.

${ }^{102} \mathrm{La}$ Nazione, May 11, 1861, and October 13, 1862. On the growth of the abolitionist movement in antebellum America, see Smith, The American Civil War, $12-13$. 
ment around the Saturday Review, which caricatured Lincoln as a rude frontiersman, the opposite of Jefferson Davis's image as "an able administrator and calm statesman." 103 For the Catholic press, the North's regime during the civil war was "a kind of military dictatorship," likened to the political situation of "occupied" Sicily, which the Church openly condemned. Suddenly discovering a concern for the treatment of prisoners and for the freedom of the press, the Catholic paper also noted that Lincoln's regime no longer respected the law of habeas corpus. It reported how numerous newspapers were banned, "following exactly the same practice as the Neapolitan Garibaldini in the service of Piedmont." ${ }^{104}$ Again, as the quotation shows, Italians interpreted the events of the Civil War within their own terms of reference. While Catholic papers questioned the motives of the Union, the liberal press pointed to the desperate actions of the Confederates, "burning their own cities, devastating their fields, prepared to suffer deprivations of any kind." 105 Apart from their respective political sympathies, Liberals and Catholics seemed to agree that "a lot of blood and violence could be spared. A war pursued with such levels of accanimento has to have the most horrific consequences." 106

Confronted with these impressions of the Civil War and the political realities of the United States, the former "model republic" increasingly lost its appeal for Italians. Life in the United States could not even be compared to conditions in Europe. Thus, reports on the Civil War echoed the earlier images of the United States in Rota's ballet, which contrasted American slavery with the values of the civilized world. ${ }^{107}$ As the liberal Nuova Antologia maintained in 1867, political life in the United States "had become extremely corrupted and violent. If one would implement this model of society and government in one of our states, it would collapse within a week." 108 More specifically, the example of the United States seemed to confirm the views of those who feared the negative consequences of democratic advances without the progress of political education. In the American South, "the honest, virtuous and well-off

${ }^{103}$ Quoted in Gabor S. Boritt, Mark E. Neely Jr., and Harold Holzer, "The European Image of Abraham Lincoln," Winterthur Portfolio 21, nos. 2/3 (Summer-Autumn 1986): 153-83, 153.

104 "Cronaca Contemporanea," Civiltà Cattolica (October 1861): 249-56.

105 Monitore di Bologna, April 28, 1865.

106 Gazzetta delle Romagne, March 12, 1865.

${ }^{107}$ See, e.g., the review of Histoire de la guerre civile en Amérique by M. le Comte de Paris, in Nuova Antologia, March 1876, Bollettino bibliografico, 703-4. This assessment was shared by the Catholic press: "La Disunione negli Stati Uniti," Civiltà Cattolica (February 1861): 312-24. For a much more positive evaluation of the United States after the Civil War, see Aurelio Saffi, "Lezioni d'oltre l'Atlantico" (1865), in Ricordi e Scritti di Aurelio Saffi, ed. Municipio di Forlì (Florence, 1902), 3:213-302. 108 "Rassegna Politica," Nuova Antologia (August 1867): 820-42, 840. 
classes retire from political life, feeling unable to give direction or to influence decisions. They leave matters to the country's least educated and least distinguished strata. Thus, democracy seems ochlocracy, where the government of the people becomes the government of the plebs. The Congress of the United States has today the reputation of being the most corrupted assembly of the entire world." 109 In assessing the views of this influential periodical it is interesting to note that, originally, Antologia had advocated the federalization of Italy, but experience taught America's former supporters a different lesson. Observing political developments across the Atlantic, Republicanism in general lost its appeal. While Mazzinians and radical democrats continued to see a link between prosperity and Republicanism, the Italian Liberals compared developments in the United States with those in Britain, coming to the conclusion that progress did not depend on the form of government. ${ }^{110}$ What a country is this, where elections are won "by means of tumultuous meetings and the use of Colts?" commented Liberal as well as Catholic papers. ${ }^{111}$ News about Andrew Johnson's conflict with Congress seemed to confirm that the American Constitution simply did not provide the stability that was needed to steer the country out of its self-incurred crisis. ${ }^{112}$

\section{Beyond THE "GoOd" UnCle Tom}

Many Italian news stories on life in the United States fit the image of American society that had emerged from Stowe's novel. Illustrated magazines reported the excesses of gambling and the violence related to this particularly crude form of making money. ${ }^{113}$ Italians agreed that America had to react with determination against organized crime, but as a country of influential penal reformers they were also concerned about the frequent application of the death

${ }^{109}$ Ibid. The article partly follows Mazzini's argument that it was due to geographical differences that the American federal model was not applicable to Italy. Rossi, The Image of America in Mazzini's Writings, 10. In this respect it is interesting to note that just a year earlier the same periodical had offered a much more positive prospect of the United States' future: "Rassegna Politica," Nuova Antologia (January 1866): 187-201, 200-201. For a more nuanced assessment, see Leonida Carpi, "Rivista politica," Rivista Bolognese di scienze, lettere, arti e scuole 1, no. 3 (March 15, 1867): 344-48. ${ }^{110}$ Almanacco Repubblicano. 1871, ed. Enrico Bignami (Lodi, 1870); "Rassegna Politica," Nuova Antologia (January 1866): 187-201, 200-201. Also "Rassegna Politica," Nuova Antologia (June 1868): 421-40, 433-34.

${ }^{111}$ Civiltà Cattolica (August 1868): 498-512, 502; also L'Universo Illustrato 3, no. 2 (October 1868): 20.

112 The president's conciliatory policies toward the South were opposed by the Radical Republicans who gained control of Congress in 1866. "Rassegna Politica," Nuova Antologia (December 1866): 840-49, 846; Civiltà Cattolica (August 1868): 498-512.

${ }^{113}$ L'Universo Illustrato 1 (November 8, 1866): 122-24. 
penalty and surprised that different states did not apply it in the same way. ${ }^{114}$ From early on the Italian press was aware of the Ku Klux Klan, which was understood as a legacy of the country's history of racial segregation. ${ }^{115}$ Meanwhile, Italian Liberals expressed concern at "a policy which results in allowing Negroes to occupy the same level in the administration of the State as Whites, who become the servants of their former slaves,"116 another problem that went back to the Civil War. Even provincial papers such as the Giornale di Sicilia reported tensions between white soldiers and black volunteers during the war, and wrote about protests against black suffrage. ${ }^{117}$ In 1867 L'Universo Illustrato maintained that most Negroes "never proved to possess any of the virtues for which they were praised in Uncle Tom's Cabin." 118 Italians started questioning the racial categories they had received from the debates about Stowe's novel. Cesare Lombroso, the Italian father of criminal anthropology, maintained that "race shapes criminal organisations," and he was convinced that the emancipation of slaves had not helped the United States to improve its general societal conditions. ${ }^{119}$ Between the $1870 \mathrm{~s}$ and the 1890s, America, along with the Italian South, became the basis for Lombroso's theories of degeneration and of the "born criminal," widely read in England and with followers around the world. In his book Sex and Character, which he dedicated to Lombroso, Otto Weininger maintained that "there has probably never been a genius among Negroes, and their morality is generally so low that the Americans ... are beginning to fear that it was an ill-considered move to emancipate them." 120 This new form of biologically informed racism contributed considerably to negative views of the United States, in Italy and across Europe.

The assassination of President Garfield in 1881 offered an opportunity to reflect again on the death of Lincoln, and the event was still explained as the consequence of the country's material and moral devastation during the Civil War. ${ }^{121}$ What impressed Europeans even more, and Italians in particular, was the fact that numerous anarchists, including the assassin of the Italian King

114 Gazzetta delle Romagne, March 7, 1865, "La Pena di Morte."

115 "Rassegna Politica," Nuova Antologia (October 1868): 413-27.

116 Ibid., 421-32, 431.

117 Giornale di Sicilia, August 22, 1865.

${ }^{118}$ L'Universo Illustrato 1 (March 23, 1867): 303.

${ }^{119}$ Cesare Lombroso, Criminal Man (1876-97), 1st and 3rd eds. (Durham, NC, 2006), 90, 128; Suzanne Stewart-Steinberg, The Pinocchio Effect: On Making Italians, 1860-1920 (Chicago, 2007), chap. 7.

${ }^{120}$ Otto Weininger, Sex and Character: An Investigation of Fundamental Principles (Bloomington, IN, 2005), 273. There existed similar concern over the capacity of East Asian immigrants to assimilate. See, e.g., Gaetano Mosca, The Ruling Class: Elementi di Scienza Politica (New York, 1939), 477.

${ }^{121}$ G. Boglietti, "Il Presidente Garfield," Nuova Antologia (October 1881): 181-207. 
Umberto I, had learned their trade in the United States. ${ }^{122}$ Errico Malatesta explained their actions as a consequence of the "infamous persecutions" and the "social injustice" they had had to endure in the United States. The Italians in particular, Malatesta claimed, were treated as "an inferior race just a little above the negroes," using an image Italians were familiar with since their first encounter with Stowe. The fact that Italian immigrants were usually also Catholics made their situation even more difficult. ${ }^{123}$ These reports overshadowed the myths about emigration as a solution to the hopeless fate of Italian peasants and workers at home. As a proverb from Basilicata says, "L'America a ci acconza e a ci uasta" (America accommodates some and ruins others); similarly popular was the simple phrase "Managgia l'America!" (Damn America!). ${ }^{124}$

Why then did the new century bring a wave of mass emigration to the United States, when for the first time Italian emigration to the United States outnumbered other destinations? ${ }^{125}$ As the work of Emilio Franzina has demonstrated, "la smania di andarsene," especially among village people, became

${ }^{122}$ According to Bologna's Resto del Carlino, anarchist circles in the United States had spent months planning the assassination of the Italian king: August 1, 1900. Lombroso argued that crime rates in the United States were particularly high in cities of high Italian and Irish immigration: Lombroso, Criminal Man, 317-18. On the connection between Italian and American anarchism, see in particular Nunzio Pernicone, "Luigi Galleani and Italian Anarchist Terrorism in the United States," Studi Emigrazione/Etudes Migrations 30, no. 111 (1993): 469-89.

${ }_{123}$ Cesare Causa, Giovanni Passanante condannato a morte per avere attentato alla vita di S. M. Umberto I Re d'Italia (Florence, 1879), 86-87; Errico Malatesta, "Anarchia e Violenza," in Malatesta, Scritti (4 vols.), vol. 3, Penseiro e volontà (Geneva, 1936; repr., 1975), 108; Errico Malatesta, "Gli Italiani all'estero," in ibid., 1:251. While Malatesta might represent an extreme view, less radical voices, as well as the government, also pointed regularly to the sad fate of Italian immigrants in the United States. See, e.g., "The Immigration from Italy for the United States," Italia: A Monthly Magazine 8 (August 1888): 50-53; Vincenzo Grossi, "L'Emigrazione Italiana in America," Nuova Antologia, 3rd ser., 55 (1895): 740-57. For a more literary account, see the impressions of the writer Giuseppe Giacosa, "Gli Italiani a New York ed a Chicago," Nuova Antologia, 3rd ser., 40 (1892): 619-40, 625. See also Claudia Dall'Osso, Voglia d'America, $32 \mathrm{ff}$. On the militant and often xenophobic aversion to Catholics migrants, see Giorgio Spini, Risorgimento e Protestanti (Naples, 1956), 221.

${ }^{124}$ Michael La Sorte, Images of Italian Greenhorn Experience (Philadelphia, 1985), 195; Andrew Rolle, The Italian Americans: Troubled Roots (New York, 1980), 29; Max Paul Friedman, "Beyond 'Voting with the Feet': Toward a Conceptual History of 'America' in European Migrant Sending Communities, 1860s to 1914," Journal of Social History 40, no. 3 (Spring 2007): 557-75, 562. On images of America in migrant communities, see Emilio Franzina, L'immaginario degli emigranti: Miti e raffigurazioni dell'esperienza italiana all'estero fra due secoli (Paese, 1992).

${ }^{125}$ During the first decade of the twentieth century, 232,945 Italians immigrated to the United States. Istituto Centrale di Statistica, Sommario di Statistiche Storiche dell'Italia, 1861-1975, 34-35. 
a contaminating folly, where entire communities decided to leave for America without any realistic expectation of what the future would hold for them. ${ }^{126}$ In 1901 the mayor of the small town of Moliterno in Carlo Levi's Lucania presented the Italian prime minister Zanardelli with the greetings of " 8,000 citizens, 3,000 of which were in America, soon to be followed by the remaining 5,000." 127 Depressing social and economic conditions at home, combined with reports about the United States' material prosperity, convinced hundreds of thousands of Europeans to cross the Atlantic permanently.

Depictions of life in the United States in the press, literature, and political debate suggest that the emigrants were fully aware that the land they sought had little in common with the idealized image of the model republic held up by the revolutionaries of the 1830s and 1840s. A famous enquiry of the Società Bibliografica Italiana among working-class readers in 1906 revealed that at least forty-nine out of 459 Italian workers had read De Amicis's classic emigration novel, Sull'Oceano, which depicted the fate of migrants with grim realism. ${ }^{128}$ However, what emigration seemed to offer was an economic opportunity. The United States was able to offer work. Therefore, emigration was less the fulfillment of a dream than the outcome of a balancing of risks. And many returned after having taken a closer look, especially once steamships lowered the cost of transatlantic travel: 58 percent of Italo-Americans returned once they had made enough money to buy land at home. ${ }^{129}$

When the wave of mass Italian migration to the United States started, Rota's ballet and other shows based on Uncle Tom's Cabin were still in performance in several Italian cities (though less so in those rural areas most affected by migration). If the outcome of the Civil War had solved the problem of slavery, ${ }^{130}$ this did not mean that Bianchi e Neri became a historical ballet. The treatment of black Americans, as depicted by Stowe, still resonated in the reports of returning labor migrants, American news items in the Italian press, and articles in illustrated magazines. The fact that many of these articles traced America's problems back to the trauma of the Civil War suggested that the conflict had left Americans in a state of moral decline, which affected society as a whole-men, women, and children.

The great Italian philosopher and liberal historian Benedetto Croce listed Stowe's novel among the key works of nineteenth-century literature. But he spoke less favorably about the United States as a country. The United States

126 "The folly of leaving." See Franzia, Dall'Arcadia in America, 69.

127 Quoted in Antonio Margariti, America! America! (Salerno, 1980), 7.

${ }^{128}$ Franzina, L'immaginario degli emigranti, 30 ff., 81.

${ }^{129}$ Friedman, "Beyond 'Voting with Their Feet,'" 558 (figures for the years after 1908)

${ }^{130}$ As argued, for instance, by Giovanni Boglietti, "Repubblicani e Democratici negli Stati-Uniti d'America," Nuova Antologia (August 1868): 766-88. 


\section{Körner}

had once been "the typical country of democracy." However, it then became paralyzed by "the conflict between advocates and opponents of slavery," an issue Europe had overcome "a millennium and a half ago" and which it was now "rooting out in her colonies." Immersed in what was basically a conflict of economic interests, the country fell out of step with the great struggle between liberalism and democracy, which characterized the progressive countries of Europe. ${ }^{131}$ While Italy's conflict in the South was often described as a Civil War in its own right, the idea of a war between brothers that cost the lives of 600,000 men remained inconceivable for a nation that had constructed the idea of its own national resurgence on the concepts of brotherhood and kinship. ${ }^{132}$

${ }^{131}$ Benedetto Croce, History of Europe in the Nineteenth Century (London, 1934), $146-47,152-53$.

132 Alberto M. Banti, La nazione del Risorgimento (Turin, 2001). See, on this particular aspect, Capellini's comment: Capellini, Ricordi di un viaggio, 148. 